\title{
KONFLIK KERJA DAN LINGKUNGAN KERJA TERHADAP KINERJA KARYAWAN PT. PARKLAND WORLD INDONESIA PLANT 2 BAGIAN STOCKFIT CELL 5 KABUPATEN SERANG-BANTEN
}

\author{
Santi ${ }^{1}$ Ende $^{2}$ Riza Wijayanti ${ }^{3}$ \\ ${ }^{1,2,3}$ Fakultas Ekonomi dan Bisnis Universitas Bina Bangsa Banten \\ Email : ${ }^{1}$ santichesanti@gmail.com
}

\begin{abstract}
ABSTRAK
Perusahaan dituntut untuk mempunyai kinerja karyawan yang handal, pada PT. Parkland World Indonesia 2 khususnya bagian Stockfit Cell 5 memiliki beberapa kendala dalam pencapaian target perusahaan yang diakibatkan kurang fokusnya karyawan saat bekerja sehingga menyebabkan turunnya kinerja karyawan. Penelitian ini bertujuan untuk mengetahui pengaruh konflik kerja dan lingkungan kerja terhadap kinerja karyawan pada PT. Parkland World Indonesia Plant 2 SerangBanten. Metode penelitian yang digunakan adalah Kuantitatif. Dengan populasi sebanyak 50 karyawan dan sampel sebanyak 50, dengan mengunakan teknik jenuh, dengan penyebaran kuisioner kepada 50 responden pada karyawan PT. Parkland World Indonesia 2 Serang-Banten. Berdasarkan analisis penelitian didapatkan nilai perhitungan dalam bentuk koefisien determinasi (R2 ) memiliki nilai 66,6\% yang cukup berkontribusi dalam keterikatan untuk pengaruh antara variabel bebas terhadap variabel terikat. Hasil uji t yaitu variabel konflik kerja memperoleh nilai thitung 7,002 > ttabel 2,010 dan lingkungan kerja memperoleh nilai thitung 4,354 > ttabel 2,010 dan nilai signifikasi lebih kecil dari 0,05. Hasil penelitian secara simultan mendapatkan hasil Fhitung sebesar 46,844 > Ftabel sebesar 2,804. Berdasarkan hasil penelitian dapat disimpulkan bahwa hubungan antara variabel konflik kerja dan variabel lingkungan kerja secara parsial dan simultan terhadap kinerja karyawan memiliki pengaruh positif bahkan sangat signifikan.
\end{abstract}

\section{Kata Kunci: Konflik Kerja, Lingkungan Kerja dan Kinerja Karyawan}

\section{ABSTRACT}

The Company is required to have a reliable employee performance, at PT. Parkland World Indonesia 2, especially Stockfit Cell 5, has some obstacles in achieving the company's target due to the lack of focus of employees while working, causing a decrease in employee performance. This research aims to determine the influence of work conflicts and work environment on employee performance at PT. Parkland World Indonesia Plant 2 Serang-Banten. The research method used is Quantitative. With a population of 50 employees and a sample of 50, using saturated techniques, with the spread of questionnaires to 50 respondents employees at PT. Parkland World Indonesia 2 Serang-Banten. Based on the analysis of the study obtained the calculation value in the form of a coefficient of determination $(R 2)$ has a value of $66.6 \%$ which contributes enough in attachment to the influence between free variables against bound variables. T test result is variable work conflict obtained tcount value 7,002 > 2,010 ttable and work environment obtained tcount value of 4,354 > 2,010 ttable and signification value less than 0.05.The results of the study simultaneously obtained the results of Fcount of 46,844 > Ftable of 2,804. Based on the results of the study, it can be concluded that the relationship between work conflict variables and work environment variables partially and simultaneously to employee performance has a positive influence even very significant.

Keywords: Work Conflict, Work Environment and Employee Performance 


\section{PENDAHULUAN}

PT. Parkland World Indonesia Plant 2 adalah perusahaan yang bergerak dalam bidang industri manufaktur yang memproduksi dan mendistribusikan sepatu, serta berdiri pada tahun 2011. Salah satu sepatu yang dibuat di parkland world indonesia 2 adalah New Balance (NB). Produk New Balance ini bertaraf internasional, sepatu-sepatu yang dihasilkanpun tidak untuk dijual di dalam negeri. Produkproduk yang dihasilkan meliputi : Sepatu Lifestyle (Gaya hidup), Sepatu Kid (Anak-anak), dan Sepatu Running (Lari). Pesaing PT. Parkland World Indonesia 2 adalah PT. Nikomas Gemilang dan PT. Adis Dimension Footwear.

Setiap perusahaan yang memproduksi sepatu pasti mereka memikirkan target produksi serta pemasarannya begitu pula dengan PT. Parkland World Indonesia 2. Dalam memenuhi target tersebut perusahaan menekankan kepada karyawan agar memiliki kinerja yang maksimal sesuai dengan standar operasional prosedur, tapi kenyataannya target yang ditetapkan tidak dilihat dari seberapa kesanggupan karyawan dalam memenuhinya kadang hal ini sering menimbulkan ketidaknyamanan yang dirasakan oleh kayawan.

Menurut Anwar Prabu Mangkunegara (2017:67) Kinerja karyawan (prestasi kerja) adalah hasil kerja secara kualitas dan kuantitas yang dicapai oleh seseorang karyawan dalam melaksanakan tugasnya sesuai dengan tanggung jawab yang diberikan kepadanya. Menurut Macmed Tun Ganyang (2018:187) Kinerja adalah tingkat efektivitas dan efisiensi yang ditunjukan oleh karyawan dalam melaksanakan tugasnya sehari-hari di suatu organisasi atau perusahaan pada periode tertentu. Yoyo Sudaryo (2018:203) Kinerja merupakan aspek penting dalam upaya pencapaian suatu tujuan. Pencapaian tujuan yang maksimal merupakan buah dari kinerja tim atau individu yang baik, begitu pula sebaliknya, kegagalan dalam mencapai sasaran yang telah dirumuskan juga merupakan akibat dari kinerja individu atau tim yang tidak optimal.

Banyak faktor yang menyebabkan terjadinya penurunan kinerja karyawan di perusahaan diantaranya Konflik Kerja. Pada Maret 2021 tercatat 10 kali keributan antar karyawan yang disebabkan oleh konflik yang terjadi antar karyawan di PT. Parkland World Indonesia Plant 2. Hal ini diketahui dari data yang diperoleh dari Serikat Pekerja Nasional (SPN) dan CR Departemen, biasanya konflik yang diadukan terjadi karena kurang baiknya komunikasi antar karyawan sehingga terjadi perselisihan antar karyawan yang tidak bisa dihindari. Dalam hal ini peran SPN dan CR sangat penting karena kepada mereka lah karyawan PT. Parkland World Indonesia 2 mengadukan masalah atau konflik yang terjadi.

Menurut Umi Farida dan Sri Hartono (2015:34) Konflik dapat muncul dimana saja, kapan saja dan bisa menimpa siapa saja. Bagi manusia tidak mungkin dapat mendhindarkannya, karena hadirnya 
Prosiding The 1st National Conference on Applied Business, Education, \& Technology (NCABET)"

Unversitas Bina Bangsa 2021

DOI Article : 10.46306/ncabet.v1i1.15

konflik sebagai akibat interaksi dengan orang lain. Dalam setiap organisasi terdapat unsur-unsur konflik, masalahnya bagaimana mengelola konflik itu sehingga tidak merugikan. Konflik bisa diartikan sebagai pertentangan atau perselisihan, sering konflik dinilai negatif dan merugikan padahal konflik adalah bagian proses sosial yang wajar dan tak mungkin dihindari.

Menurut Rusdiana (2015:162) Konflik adalah kondisi terjadinya ketidakcocokan antarnilai atau tujuan yang ingin dicapai, baik yang ada dalam diri individu maupun dalam hubungannya dengan orang lain. Kondisi yang telah kemukakan tersebut dapat mengganggu, bahkan menghambat tercapainya emosi atau stres yang mempengaruhi efisiensi dan produktivitas kerja. Menurut Weni Puspita (2018:3) Konflik merupakan sebuah situasi, dimana dua orang atau lebih menginginkan tujuan-tujuan yang menurut persepsi mereka dapat dicapai oleh salah seorang diantara mereka, tetapi hal itu tidak mungkin dicapai oleh kedua belah pihak. Mahmudah Enny W (2019:72) Konflik berasal dari kata kerja latin configere yang berarti saling memukul. Secara sosiologis, konflik diartikan sebagai suatu proses sosial antara dua orang atau lebih dimana salah satu pihak berusaha menyingkirkan pihak lain dengan menghancurkannya atau membuatnya tidak berdaya.

Hal lain yang mempengaruhi kinerja karyawan adalah lingkungan kerja. Jika lingkungan kerja karyawan tidak nyaman maka dapat membuat karyawan tidak fokus dalam mencapai kinerja maksimal. Lingkungan kerja juga dapat diartikan sebagai susasana kerja. Suasana yang suportif akan membuat produktivitas karyawan lebih tinggi, sebaliknya jika suasana kerja tidak suportif akan membuat produktivitas karyawan tidak kondusif. Berdasarkan observasi melalui wawancara dengan beberapa karyawan PT. Parkland World Indonesia Plant 2, menyatakan bahwa lingkungan kerja fisik yang ada di area stockfit cell 5 kurang kondusif terbukti dengan tidak adanya blower yang mengakibatkan sirkulasi udara tidak optimal dan suhu konveyor tidak di sesuaikan dengan artikel sepatu yang jalan sehingga mengakibatkan barang cacat dan berdampak terhadap target produksi.

Menurut I Gusti Putu (2014:40) Lingkungan yaitu segala sesuatu di sekitar subyek manusia yang terkait dengan aktivitasnya. Elemen lingkungan adalah hal-hal yang terkait dengan tanah, udara, air, sumber daya alam, flora, fauna, manusia dan hubungan antar faktor-faktor tersebut. Menurut Agung Prihantoro (2015:20) Lingkungan kerja adalah segala sesuatu yang ada disekitar tenaga kerja dan dapat mempengaruhi dirinya dalam menjalankan tugas-tugas yang dibebankan kepadanya. Danang Sunyoto (2012:43) Lingkungan kerja segala sesuatu yang ada disekitar para pekerja dan yang dapat mempengaruhi dirinya dalam menjalankan tugas-tugas yang dibebankan, misalkan kebersihan, musik, penerangan, dan lain-lain. 
Berdasarkan latar belakang masalah di atas, maka penulis mengidentifikasi beberapa permasalahan, diantaranya yaitu Tingkat keberhasilan target menurun karena kinerja karyawan yang kurang maksimal, Rendahnya kedisiplinan karyawan dalam pekerjaannya, Hubungan kerja antar karyawan menjadi renggang, muncul rasa ketidakpercayaan dan mudah curiga. Sehingga komunikasi yang terjalin tidak harmonis, Ketidaknyamanan masih dirasakan karyawan dikarenakan lingkungan kerja yang kurang kondusif. Adapun tujuan dari penelitian ini adalah:

1. Untuk menguji Pengaruh Konflik Kerja terhadap Kinerja Karyawan pada bagian Stockfit cell 5 PT. Parkland World Indonesia 2 Serang-Banten.

2. Untuk menguji Pengaruh Lingkungan Kerja terhadap Kinerja Karyawan pada bagian Stockfit cell 5 PT. Parkland World Indonesia 2 Serang-Banten.

3. Untuk menguji Pengaruh Konflik Kerja dan Lingkungan Kerja terhadap Kinerja Karyawan pada bagian Stockfit cell 5 PT. Parkland World Indonnesia 2 Serang-Banten.

\section{METODE PENELITIAN}

Metode penelitian adalah cara ilmiah untuk mendapatkan data dengan tujuan dan kegunaan tertentu (Sugiyono, 2015:2). Berdasarkan teknik pengumpulan data, maka penelitian ini dilakukan dengan metode kuantitatif. Menurut Sugiyono metode kuantitatif dapat diartikan sebagai metode penelitian yang berlandaskan pada filsafat positivisme, digunakan untuk meneliti pada populasi atau sampel tertentu, pengumpulan data menggunakan instrumen penelitian, analisis data bersifat kuantitatif, dengan tujuan untuk menguji hipotesis yang sudah di tetapkan. Pada penelitian ini merupakan penelitian kuantitatif, penelitian untuk menentukan hubungan antar variabel dalam sebuah populasi.

Lokasi pelaksanaan penelitian ini adalah PT. Parkland World Indonesia Plant 2 yang beralamatkan di Jl. Lanud Gorda Km.68 Desa Julang Kec. Cikande, Kab. Serang-Banten Indonesia. Populasi pada penelitian ini adalah karyawan departemen produksi bagian Stockfit Cell 5 yang berjumlah 50 karyawan tetap. Menurut Ende dan Naufal Affandi (2019: 60) Sampel adalah bagian dari jumlah dan karakteristik yang dimiliki oleh populasi tersebut. Karena populasi relatif kecil maka penarikan sampel menggunakan teknik sampling jenuh. Sampel jenuh dapat juga sering diartikan sampel yang sudah maksimum, karena ditambah berapapun jumlahnya tidak akan mengubah keterwakilan populasi. Berdasarkan pendapat ahli tersebut sampel pada penelitian ini yaitu seluruh jumlah populasi dijadikan sampel yang berjumlah 50 karyawan.

\section{HASIL DAN PEMBAHASAN}




\subsection{Analisis Regresi Berganda (R)}

\begin{tabular}{|c|c|c|c|c|}
\hline \multicolumn{5}{|c|}{ Model Summary } \\
\hline Model & $R$ & R Square & Adjusted R Square & Std. Error of the Estimate \\
\hline 1 & $.816^{\mathrm{a}}$ & .666 & .652 & 5.78827 \\
\hline
\end{tabular}

a. Predictors: (Constant), total_x2, total_x1

b. Dependen Variabel: total_y

Dari output tersebut nilai Koefisien korelasi $(\mathrm{R})=0,816$ ini berarti bahwa kekuatan hubungan antara variabel $\mathrm{X}_{1}$ dan $\mathrm{X}_{2}$ secara bersamaan dengan $\mathrm{Y}$ adalah 0,816. Dengan mengacu pada tabel koefisien korelasi, tingkat hubungannya berada pada rentang 0,800 - 1.000 artinya hubungannya sangat kuat.

\subsection{Analisis Regresi Liniear Berganda}

\begin{tabular}{|c|c|c|c|c|c|c|}
\hline \multicolumn{7}{|c|}{ Coefficients $^{a}$} \\
\hline \multirow[b]{2}{*}{ Model } & & \multicolumn{2}{|c|}{ Unstandardized Coefficients } & \multirow{2}{*}{$\begin{array}{l}\text { Standardized } \\
\text { Coefficients } \\
\text { Beta }\end{array}$} & \multirow[b]{2}{*}{$\mathrm{t}$} & \multirow[b]{2}{*}{ Sig. } \\
\hline & & $B$ & Std. Error & & & \\
\hline \multirow[t]{3}{*}{1} & (Constant) & -24.799 & 9.072 & & -2.733 & .009 \\
\hline & total_x1 & .825 & .118 & .617 & 7.002 & .000 \\
\hline & total_x2 & .518 & .119 & .384 & 4.354 & .000 \\
\hline
\end{tabular}

a. Dependent Variable: Kinerja Karyawan

Persamaan garis regresi:

$$
\begin{gathered}
\mathrm{Y}=\alpha+\beta_{1} X_{1}+\beta_{2} X_{2} \\
\mathrm{Y}=-24.799+0,825 \mathrm{X}_{1}+0,518 \mathrm{X}_{2}
\end{gathered}
$$

a. Konstanta sebesar -24,799 artinya jika Konflik Kerja $\left(\mathrm{X}_{1}\right)$ dan Lingkungan Kerja $\left(\mathrm{X}_{2}\right)$ nilainya adalah 1, maka Kinerja Karyawan (Y) nilainya adalah -24,799.

b. Koefisien regresi variabel Konflik Kerja $\left(\mathrm{X}_{1}\right)$ sebesar 0,825 artinya jika variabel independen lain nilainya tetap dan Konflik Kerja mengalami kenaikan 1 satuan, maka Kinerja Karyawan (Y) akan mengalami kenaikan sebesar 0,825. Semakin naik Konflik Kerja maka Kinerja Karyawan akan meningkat.

c. Koefisien regresi variabel Lingkungan Kerja $\left(\mathrm{X}_{2}\right)$ sebesar 0,518 artinya jika variabel independen lain nilainya tetap dan Lingkungan Kerja mengalami kenaikan 1 satuan, maka Kinerja Karyawan (Y) akan 
mengalami peningkatan sebesar 0,518. Koefisien bernilai positif artinya terjadi hubungan positif antara Lingkungan Kerja dengan Kinerja Karyawan, semakin naik Lingkungan Kerja maka Kinerja Karyawan semakin meningkat.

\subsection{Analisis Koefisien Determinasi $\left(\mathbf{R}^{2}\right)$}

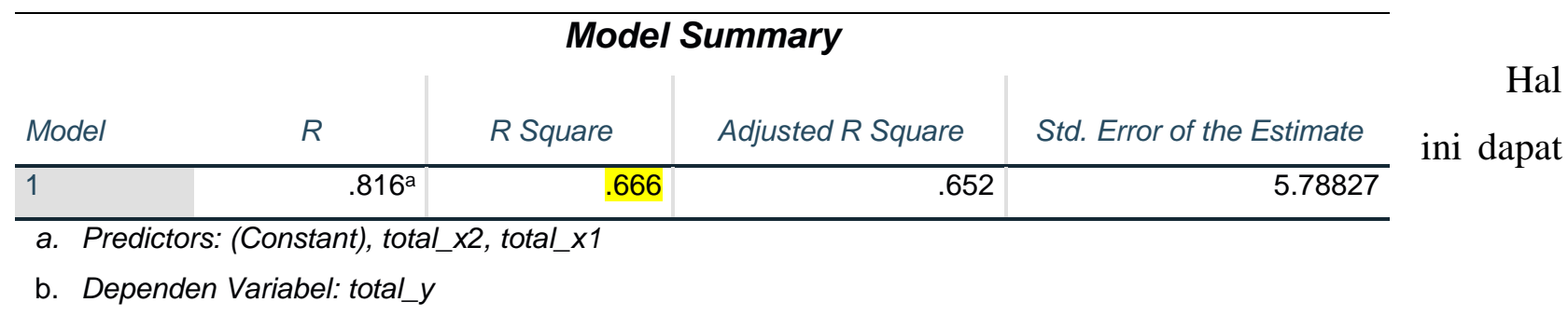

disimpulkan bahwa besarnya pengaruh variabel bebas terhadap variabel terikat adalah $66,6 \%$ sedangkan sisanya 33,4\% dipengaruhi oleh variabel lain diluar penelitian.

\section{Kontribusi Variabel Konflik Kerja $\left(\mathbf{X}_{1}\right)$ terhadap Kinerja Karyawan (Y)}

Berdasarkan Gambar tersebut Koefisien Determinasi pengaruh langsung $\mathrm{X}_{1}$ terhadap Y adalah 0,617 x

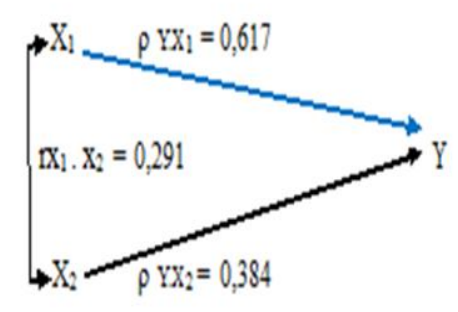

$0,617=0,381$ dan pengaruh $\mathrm{X}_{1}$ terhadap $\mathrm{Y}$ melalui $\mathrm{X}_{2}$ adalah $0,617 \mathrm{x}$ $0,291 \times 0,384=0,069$. Maka pengaruh $\mathrm{X}_{1}$ terhadap $\mathrm{Y}$ adalah $0,381+$ $0,069=0,45$ atau 45\%. Hal ini dapat disimpulkan bahwa Konflik Kerja $\left(\mathrm{X}_{1}\right)$ memberikan kontribusi sebesar $45 \%$ terhadap Kinerja Karyawan (Y) pada PT. Parkland World Indonesia Plant 2 Serang-Banten.

Kontribusi Variabel Lingkungan Kerja $\left(\mathbf{X}_{2}\right)$ terhadap Kinerja Karyawan (Y) 
Prosiding The 1st National Conference on Applied Business, Education, \& Technology (NCABET)"

Unversitas Bina Bangsa 2021

DOI Article : 10.46306/ncabet.v1i1.15

Berdasarkan Gambar tersebut Koefisien Determinasi pengaruh langsung $\mathrm{X}_{2}$ terhadap $\mathrm{Y}$ adalah 0,384 x 0,384=

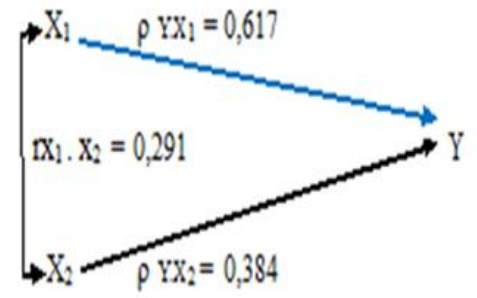

0,147 dan pengaruh $\mathrm{X}_{2}$ terhadap $\mathrm{Y}$ melalui $\mathrm{X}_{1}$ adalah $0,384 \times 0,291 \times 0,617$ $=0,069$. Maka pengaruh $\mathrm{X}_{2}$ terhadap $\mathrm{Y}$ adalah $0,147+0,069=0,216$ atau 21,6\%. Hal ini dapat disimpulkan bahwa Lingkungan Kerja $\left(\mathrm{X}_{2}\right)$ memberikan kontribusi sebesar 21,6\% terhadap Kinerja Karyawan (Y) pada PT. Parkland World Indonesia Plant 2 Serang-Banten.

\subsection{Pengujian Hipotesis}

\subsubsection{Uji Parsial (Uji T)}

\begin{tabular}{|c|c|c|c|c|c|c|}
\hline \multicolumn{7}{|c|}{ Coefficients $^{a}$} \\
\hline \multirow{2}{*}{\multicolumn{2}{|c|}{ Model }} & \multicolumn{2}{|c|}{ Unstandardized Coefficients } & \multirow{2}{*}{$\begin{array}{c}\text { Standardized } \\
\text { Coefficients } \\
\text { Beta }\end{array}$} & \multirow[b]{2}{*}{$T$} & \multirow[b]{2}{*}{ Sig. } \\
\hline & & $B$ & Std. Error & & & \\
\hline \multirow[t]{3}{*}{1} & (Constant) & -24.799 & 9.072 & & -2.733 & .009 \\
\hline & total_x1 & .825 & .118 & .617 & 7.002 & .000 \\
\hline & total_x2 & .518 & .119 & .384 & 4.354 & .000 \\
\hline
\end{tabular}

a. Dependent Variable: total_y

Berdasarkan Tabel di atas, dapat dilakukan pengujian mengenai konflik kerja dan lingkungan kerja terhadap kinerja karyawan dengan melakukan langkah-langkah sebagai berikut:

1. Uji - T Konflik Kerja $\left(\mathrm{X}_{1}\right)$

Untuk menguji variabel bebas Konflik Kerja ( $\left.\mathrm{X}_{1}\right)$ terhadap Kinerja Karyawan $(\mathrm{Y})$ dilakukan dengan langkah-langkah sebagai berikut:

1) Merumuskan Hipotesis Statistik

$\mathrm{H}_{0}: \beta=0$, Tidak terdapat pengaruh antara Konflik Kerja $\left(\mathrm{X}_{1}\right)$ terhadap Kinerja Karyawan $(\mathrm{Y})$

$\mathrm{H}_{\mathrm{a}}: \beta \neq 0$, Terdapat pengaruh yang signifikan antara Konflik Kerja $\left(\mathrm{X}_{1}\right)$ terhadap Kinerja Karyawan (Y)

2) Menentukan $t_{\text {tabel }}$

Menentukan taraf nyata $(\alpha)=5 \%$. Derajat bebas $(\mathrm{dk})=\mathrm{n}-\mathrm{k}=50-2=48$, maka nilai tabel yaitu $\mathrm{t}(\alpha: \mathrm{dk})=$ $(0,05: 48)=2,010($ tabel distribusi $\mathrm{t})$.

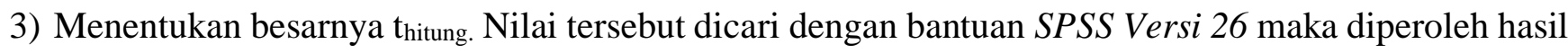
thitung sebesar 7,002

4) Kriteria Pengujian 
$\mathrm{H}_{0}$ diterima bila: $\mathrm{t}_{\text {hitung }} \leq \mathrm{t}_{\text {tabel }}$ atau nilai signifikan $\geq \alpha(0,05)$

$\mathrm{H}_{0}$ ditolak bila: $\mathrm{t}_{\text {hitung }} \geq \mathrm{t}_{\text {tabel }}$ atau nilai signifikan $\leq \alpha(0,05)$

Karena nila $t_{\text {hitung }}(7,002>2,010)$ dan nilai signifikasi $0,000<(0,05)$, maka $\mathrm{H}_{0}$ ditolak dan $\mathrm{H}_{\mathrm{a}}$ diterima. Berdasarkan uji signifikan diperoleh yang positif dan signifikan antara Konflik Kerja $\left(\mathrm{X}_{1}\right)$ terhadap Kinerja Karyawan (Y) pada PT. Parkland World Indonesia Plant 2.

\section{Daerah Pengujian Kurva Uji t Konflik Kerja $\left(X_{1}\right)$ terhadap Kinerja Karyawan}

(Y)

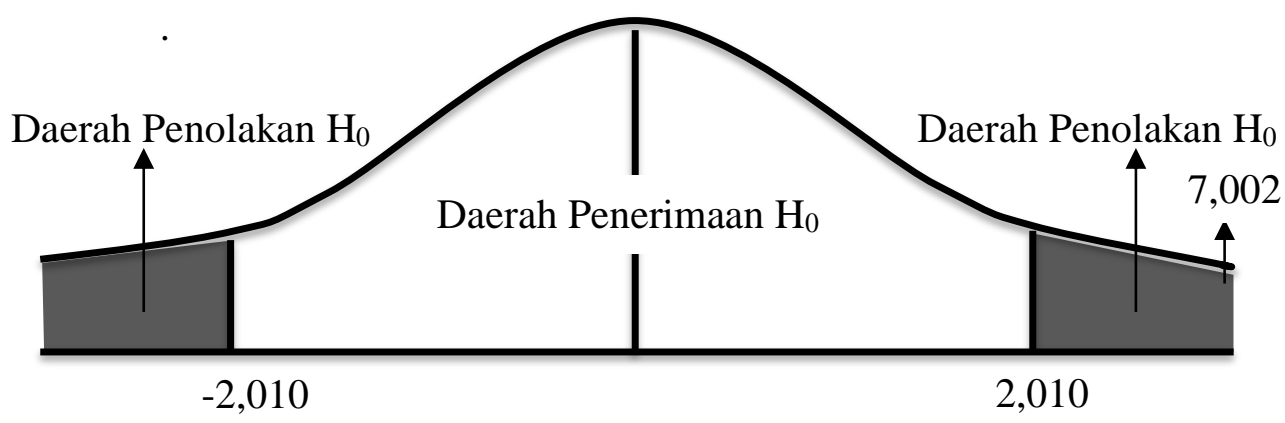

\section{Uji - T Lingkungan Kerja $\left(\mathrm{X}_{2}\right)$}

Untuk menguji variabel bebas Lingkungan Kerja $\left(\mathrm{X}_{2}\right)$ terhadap Kinerja Karyawan $(\mathrm{Y})$ dilakukan dengan langkah-langkah sebagai berikut:

1) Merumuskan Hipotesis Statistik

$\mathrm{H}_{0}: \beta=0$, Tidak dapat pengaruh yang signifikan antara Lingkungan Kerja $\left(\mathrm{X}_{2}\right)$ terhadap Kinerja Karyawan (Y)

$\mathrm{H}_{\mathrm{a}}: \beta \neq 0$, Terdapat pengaruh yang signifikan antara Lingkungan Kerja $\left(\mathrm{X}_{2}\right)$ terhadap Kinerja Karyawan (Y)

2) Menentuka tabel

Menentukan taraf nyata $(\alpha)=5 \%$. Derajat bebas $(\mathrm{dk})=\mathrm{n}-\mathrm{k}=50-2=48$, maka nilai tabel yaitu $\mathrm{t}(\alpha$ : $\mathrm{dk})=(0,05: 48)=2,010($ tabel distribusi $\mathrm{t})$.

3) Menentukan besarnya thitung. Nilai tersebut dicari dengan bantuan SPSS Versi 26 maka diperoleh hasil $t_{\text {hitung }}$ sebesar 4,354

4) Kriteria Pengujian

$\mathrm{H}_{0}$ diterima bila : $\mathrm{t}_{\text {hitung }} \leq \mathrm{t}_{\text {tabel }}$ atau nilai signifikan nilai $\geq \alpha(0,05)$

$\mathrm{H}_{0}$ ditolak bila : $\mathrm{t}_{\text {hitung }} \geq \mathrm{t}_{\text {tabel }}$ atau nilai signifikan $\leq \alpha(0,05)$ 
Prosiding The 1st National Conference on Applied Business, Education, \& Technology (NCABET)"

Unversitas Bina Bangsa 2021

DOI Article : 10.46306/ncabet.v1i1.15

Karena nilai $t_{\text {hitung }}(4,354>2,010)$ dan nilai signifikasi $0,000<(0,05)$, maka $\mathrm{H}_{0}$ ditolak dan $\mathrm{H}_{\mathrm{a}}$ diterima.

Berdasarkan uji signifikan diperoleh yang positif dan signifikan antara Lingkungan Kerja $\left(\mathrm{X}_{2}\right)$ terhadap Kinerja Karyawan (Y) pada PT. Parklan World Indonesia Plant 2.

\section{Daerah Pengujian Kurva Uji t Lingkungan Kerja $\left(X_{2}\right)$ terhadap Kinerja Karyawan}

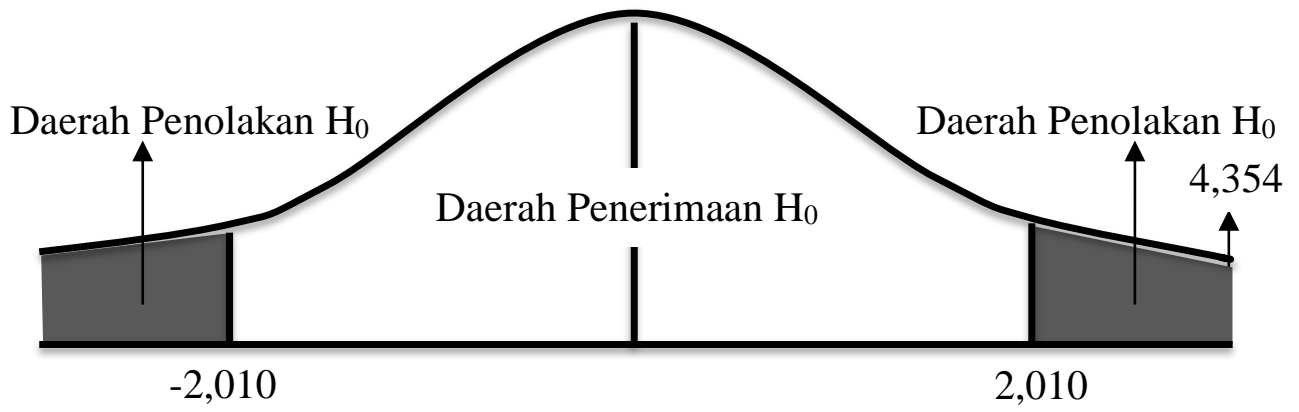

\subsubsection{Uji Simultan (Uji F)}

\begin{tabular}{|c|c|c|c|c|c|c|}
\hline \multicolumn{7}{|c|}{ ANOVA $^{a}$} \\
\hline Model & & Sum of Squares & $D f$ & Mean Square & $F$ & Sig. \\
\hline \multirow[t]{3}{*}{1} & Regression & 3138.928 & 2 & 1569.464 & 46.844 & $.000^{\mathrm{b}}$ \\
\hline & Residual & 1574.692 & 47 & 33.504 & & \\
\hline & Total & 4713.620 & 49 & & & \\
\hline
\end{tabular}

a. Dependent Variable: Kinerja Karyawan

b. Predictors: (Constant), Lingkungan Kerja, Konflik Kerja

Dengan tingkat keyakinan sebesar 5\% atau 0,05

$\mathrm{Df}_{1}=\mathrm{K}-1(3-1)=2$

$\mathrm{Df}_{2}=\mathrm{N}-\mathrm{K}(50-3)=47$

Diketahui nilai $F_{\text {tabel }}$ sebesar 2,802 dari hasil perhitungan didapat nilai $F_{\text {hitung }}=46,844$ untuk menentukan apakah pengaruhnya signifikan atau tidak, maka dilakukan perbandingan nilai $\mathrm{F}_{\text {hitung }}=$ $46,844>\mathrm{F}_{\text {tabel }} 2,802$.

Berdasarkan Tabel 4.23 datas hasil pengolahan SPSS Versi 26 diperoleh nilai $\mathrm{F}_{\text {hitung }}$ sebesar 46,844 hasil ini kemudian dibandingkan dengan $\mathrm{F}_{\text {tabel }}$ dengan nilai 2,802. Dengan tingkat signifikan $(\alpha)$ sebesar 5\% (0,05). Karena nilai $F_{\text {hitung }}(46,844) \geq F_{\text {tabel }}(2,802)$, maka $\mathrm{H}_{0}$ ditolak, sehingga dapat disimpulkan bahwa terdapat pengaruh yang positif antara variabel Konflik Kerja ( $\left.\mathrm{X}_{1}\right)$, dan Lingkungan Kerja $\left(\mathrm{X}_{2}\right)$ terhadap Kinerja Karyawan (Y) pada PT. Parkland World Indonesia Plant 2. 
Dari output SPSS Versi 26 diatas diketahui nilai signifikansi sebesar 0,000. Karena nilai signifikansi $0,000 \leq 0,05$ sesuai dengan dasar pengambilan keputusan dalam uji $\mathrm{F}$ maka dapat disimpulkan pula bahwa Konflik Kerja $\left(\mathrm{X}_{1}\right)$, dan Lingkungan Kerja $\left(\mathrm{X}_{2}\right)$ secara simultan berpengaruh terhadap Kinerja Karyawan (Y) pada PT. Parkland World Indonesia Plant 2.

\subsection{Pembahasan Hasil Penelitian}

\subsubsection{Pengaruh Konflik Kerja terhadap Kinerja Karyawan}

Berdasarkan hasil output di atas bahwa nilai thitung variabel konflik kerja sebesar 7,002 ini berarti nilai thitung > ttabel atau 7,002 > 2,010 dan nilai signifikasi lebih kecil dari pada 0,05 yaitu 0,000 dengan taraf signifikasi < 0,05. Maka dapat disimpulakan bahwa konflik kerja berpengaruh terhadap kinerja karyawan dan dari hasil output di atas dapat dibuat interprestasi korelasi yaitu sebesar 0,729 yang berarti terdapat korelasi signifikan kuat karena 0,729 berada pada interval 0,05 > 0,75 (kuat). Artinya hal ini membuktikan bahwa implementasi konflik kerja yang menjadi nilai dan perilaku dalam aktivitas kerja karyawan dilaksanakan dengan baik dan akan mendukung adanya kinerja karyawan. Dari hasil jawaban responden, terkait kuisioner yang telah disebar tentang konflik kerja semua responden menjawab setuju. Hal ini membuktikan bahwa semakin tinggi konflik yang dialami karyawan maka kinerja yang dihasilkan tidak akan terpenuhi. Maka dari itu perlu adanya perbaikan terkait penyelesaian konflik diperusahaan dengan cara melibatkan karyawan dalam proses penyelesaian, memisahkan pihak-pihak yang memiliki konflik, serta mendengarkan pihak yang terlibat konflik.

\subsubsection{Pengaruh Lingkungan Kerja terhadap Kinerja Karyawan}

Adapun hasil output lingkungan kerja terhadap kinerja karyawan di atas bahwa nilai thitung variabel lingkungan kerja sebesar 4,354 ini berarti nilai $t_{\text {hitung }}>t_{\text {tabel atau }} 4,354>2,010$ dan nilai signifikasi lebih kecil dari 0,05 yaitu 0,000 dengan taraf signifikasi < 0,05. Maka dapat disimpulkan bahwa lingkungan kerja berpengaruh terhadap kinerja karyawan dan dari hasil output di atas dapat dibuat interprestasi korelasi yaitu sebesar 0,563 yang berarti terdapat korelasi signifikan sedang karena 0,563 berada pada interval 0,04>0,599 (sedang). Artinya apabila variabel $\mathrm{X}_{2}$ (lingkungan kerja) ditingkatkan akan meningkatkan variabel Y (kinerja karyawan). Dari hasil jawaban responden, terkait kuisioner yang telah disebar tentang lingkungan kerja terdapat 1 responden menjawab kurang setuju pada poin Pertukaran Udara. Maka dari itu perlu adanya perbaikan mengenai penyesuaian suhu konveyor dengan material sepatu agar bisa mendapat hasil yang maksimal.

\subsubsection{Pengaruh Konflik Kerja dan Lingkungan Kerja terhadap Kinerja Karyawan}


Prosiding The 1st National Conference on Applied Business, Education, \& Technology (NCABET)"

Unversitas Bina Bangsa 2021

DOI Article : 10.46306/ncabet.v1i1.15

Berdasarkan tabel diatas diperoleh nilai probabilitas (sig.F change) $=0,000$. Karena nilai sig.F change $0,000<0,05$, maka keputusannya adalah $\mathrm{H}_{0}$ ditolak dan $\mathrm{H}_{\mathrm{a}}$ diterima. Artinya variabel bebas secara simultan berpengaruh terhadap variabel terikat. Selanjutnya nilai korelasi antara variabel bebas terhadap variabel terikat sebesar 0,816, artinya bahwa hubungan antara variabel bebas terhadap variabel terikat berada pada nilai interval 0,08 - 1,00 (sangat kuat). Artinya apabila variabel bebas ditingkatkan akan meningkatkan variabel terikat dengan hubungan yang sangat kuat, besarnya pengaruh variabel bebas terhadap variabel terikat adalah 66,6\% sedangkan sisanya 33,4\% di pengaruhi oleh variabel lain diluar penelitian.

\section{KESIMPULAN DAN SARAN}

\subsection{Kesimpulan}

Berdasarkan data hasil penelitian yang telah diperoleh, maka peneliti dapat menarik kesimpulan sebagai berikut:

1. Terdapat pengaruh positif dan signifikan Konflik Kerja $\left(\mathrm{X}_{1}\right)$ terhadap Kinerja Karyawan $(\mathrm{Y})$ pada PT. Parkland World Indonesia Plant 2 Bagian Stockfit Cell 5 Kabupaten Serang-Banten.

2. Terdapat pengaruh positif dan signifikan Lingkungan Kerja $\left(\mathrm{X}_{2}\right)$ terhadap Kinerja Karyawan $(\mathrm{Y})$ pada PT. Parkland World Indonesia Plant 2 Bagian Stockfit Cell 5 Kabupaten Serang-Banten.

3. Terdapat pengaruh positif dan signifikan secara bersama-sama Gaya Konflik Kerja $\left(\mathrm{X}_{1}\right)$ dan Lingkungan Kerja $\left(\mathrm{X}_{2}\right)$ terhadap Kinerja Karyawan (Y) pada PT. Parkland World Indonesia Plant 2 Bagian Stockfit Cell 5 Kabupaten Serang-Banten.

\subsection{Saran}

Berdasarkan pada kesimpulan dan implikasi di atas, maka saran dari penelitian ini adalah sebagai berikut:

1. Untuk variabel Kinerja Karyawan diharapkan para karyawan PT. Parkland World Indonesia Plant 2 bagian Stockfit Cell 5 agar lebih meningkatkan kinerjanya melalui pencapaian hasil kerja yang lebih maksimal sehingga dapat mencapai target yang telah ditentukan oleh perusahaan.

2. Untuk variabel Konflik Kerja, perlu adanya sosialisai tim manajemen serta pimpinan departemen mengenai NB-CoC (New Balance Code of Condact) yang salah satunya menerangkan tentang anti balas dendam di setiap bagian terkhusus di bagian stockfit cell 5, sehingga dapat memotivasi karyawan untuk mengetahui tingkatan konflik yang berakibat balas dendam. Karena dengan menurunnya tingkat konflik maka kinerja karyawan akan semakin meningkat. 
3. Untuk variabel Lingkungan Kerja, pentingnya meningkatkan suasana lingkungan kerja yang baik dalam membantu meningkatkan kinerja karyawan terutama dalam hal ketersediaan fasilitas di tempat kerja. Maka dari itu perusahaan harus memperhatikan kondisi lingkungan fisik yang ada di area produksi, karena dengan lingkungan kerja yang kondusif kinerja karyawan pun akan efektif.

\section{UCAPAN TERIMAKASIH}

1. Kepada kedua orang tua yang senantiasa memberikan do'a dan dukungannya sehingga penulis dapat menyelesaikan penelitian ini.

2. Dr. H.Furtasan Ali Yusuf, S.E., S.Kom., M.M, selaku Rektor Universitas Bina Bangsa yang telah berperan aktif dalam meningkatkan mutu dan kualitas Universitas Bina Bangsa menjadi perguruan tinggi yang lebih baik.

3. Kepada seluruh Dosen, staf administrasi, rekan-rekan mahasiswa dan sahabat yang telah memberikan bantuan sehingga penulis dapat menyelesaikan penelitian ini.

\section{DAFTAR PUSTAKA}

Awantara I Gusti Putu Diva. 2014. Sistem Manajemen Lingkungan: Perspektif Agrokompleks. Yogyakarta: Deepublish.

Ende, dan Naufal Affandi. 2019. Metodologi Penelitian: Konsep dan Penerapan Aplikasi Statistik. Depok: RAJAWALI PERS.

Faridah Umi, dan Sri Hartono. 2015. Manajemen Sumber Daya II. Ponorogo: UNMUH PONOROGO PRESS.

Ganyang Macmed Tun. 2018. Manajemen Sumber Daya Manusia Konsep dan Realita. Bogor: IN MEDIA.

Sudaryo Yoyo, Agus Aribowo dan Nunung Ayu Sofiati. 2018. Manajemen Sumber Daya Manusia: Kompensasi Tidak Langsung dan Lingkungan Kerja Fisik. Bandung: Penerbit Andi.

Mangkunegara Anwar Prabu. 2017. Manajemen Sumber Daya Manusia Perusahaan. Bandung: PT REMAJA ROSDAKARYA.

Prihantoro Agung. 2015. Peningkatan Kinerja Sumber Daya Manusia Melalui Motivasi, Disiplin, Lingkungan Kerja, dan Komitmen. Sleman: Deeepublish.

Puspita Weni. 2018. Manajemen Konflik: Suatu Pendekatan Psikologi, Komunikasi, dan Pendidikan. Yogyakarta: CV BUDI UTAMA.

Rusdiana. 2015. Manajemen Konflik. Bandung: CV PUSTAKA SETIA. 
Prosiding The 1st National Conference on Applied Business, Education, \& Technology (NCABET)"

Unversitas Bina Bangsa 2021

DOI Article : 10.46306/ncabet.v1i1.15

Sugiyono. 2015. Metode Penelitian Kuantitatif Kualitatif dan R\&D. Bandung: ALFABETA.

Sunyoto Danang. 2012. Manajemen Sumber Daya Manusia. Jakarta: PT. Buku Seru.

W Mahmudah Enny. 2019. Manajemen Sumber Daya Manusia. Surabaya: UBHARA Manajemen press. 